\title{
A New Species of Dallasiellus Berg (Hemiptera: Heteroptera: Cydnidae) from Caribbean
}

\author{
Leonel Marrero Artabe ${ }^{1 *}$, María C. Mayorga Martínez² \\ ${ }^{1}$ University of Matanzas, Matanzas, Cuba \\ ${ }^{2}$ Institute of Biology, Universidad Nacional Autónoma de México (UNAM), México City, México \\ Email: *leonel.marrero@umcc.cu
}

Received 7 February 2014; revised 21 March 2014; accepted 1 April 2014

Copyright (C) 2014 by authors and Scientific Research Publishing Inc.

This work is licensed under the Creative Commons Attribution International License (CC BY). http://creativecommons.org/licenses/by/4.0/

(c) (i) Open Access

\begin{abstract}
The genus Dallasiellus Berg (Hemiptera: Cydnidae) is revised with the description of a new species from Caribbean, Dallasiellus varaderensis nov. sp. A diagnosis of species is based on external morphology of males and genitalia examination. Dorsal view of adults and parameres are illustrated. Notes about their biology and host plants are briefly discussed.
\end{abstract}

\section{Keywords}

\section{Burrower Bugs, Dallasiellus, New Species, Diagnoses, Turfgrass, Caribbean}

\section{Introduction}

Members of the Cydnidae family are called burrowing bugs; more than 88 genera and about 680 species are recorded [1]. They have generally been considered of little economic importance, but up to date almost 30 species have been reported as pests [2]-[4]. Some species causing damages on turfgrass in a Golf Club from Caribbean have been detected recently [5]. However, the biological information about these insects is not very well-known yet.

One of the most important studies of this group was the Revision of the Western Hemisphere fauna of Cydnidae carried out by Froeschner [6]. Just the revision works reported by [6], the description of species for Puerto Rico [7] and the records for Dominican Republic and Haiti have been notified [8]. Although some works about Cuban cydnids have been reported [6] [9], these taxa have received little attention in recent years. The genus Dallasiellus Berg (1901) is widely distributed from Southeast of United States, across Mexico, Antilles to South

*Corresponding author. 
America and 29 species are listed [6]. In the literature, taxonomic studies focusing on Dallasiellus occurrence on Caribbean are a few. Until now, only two species (Dallasiellus lugubris Stal and Dallasiellus scitus Walker) have been reported from Cuba [10] [11] and limited amount of data impede a better understanding of these taxa. The aim of this work is to describe a new species of Dallasiellus Berg from Caribbean.

\section{Material and Methods}

\subsection{Location}

This work was carried out during 2010, as a part of field activities of the Project Pest Arthropods associated to turfgrass of Varadero Golf Course, supporting by Ministerio de Ciencia Tecnología y Medio Ambiente de Cuba (CITMA). The study area is located at Las Morlas Highway $15^{\text {th }} \mathrm{Km}$, at north coast of Hicacos Peninsula $\left(23^{\circ} 04^{\prime} \mathrm{N}\right.$ and $\left.81^{\circ} 17^{\prime} \mathrm{W}\right)$, Varadero municipality, Matanzas province, Cuba (Figure 1). The area has sandy soils and is dominated by turfgrass (Bermuda 328 and Tifdwarf varieties). Ficus elastica Roxb., Guaiacum sanctun L., Scindapsus aureus Engl. within the coastal dune vegetation are also there.

\subsection{Collection of Species and Taxonomic Description}

The species collection and preservation carried out in the present study complied all the required authorization according to Ministerio de Ciencia Tecnología y Medio Ambiente de Cuba (CITMA) and the laws of Mexico. Soil samplings were carried out during November and December 2010, in correspondence with the dry period. Temperature, air humidity and rain showed a monthly averaged of $21.8^{\circ} \mathrm{C}, 74 \%$ and $58.9 \mathrm{~mm}$, respectively.

Insects were collected in the green of $14^{\text {th }}$ and $17^{\text {th }}$ holes by means of a hole cuter device and a shovel. Specimens were stored in alcohol 70\% and transferred to the Biology Institute of Universidad Nacional Autonoma de Mexico (UNAM), where two male were dissected. Identification of species was based on external morphology of males. An exhaustive genitalia examination using microscopic techniques was made. Species diagnosis presented here was based on different taxonomic keys [6] [11] [12].

All measurements were made with a Stemi SV 8 stereomicroscope equipped with an ocular graticule and metrics are in millimetres and given in brackets ( ). Genitalia were dissected and parameres were separated, placed in glycerin and described under a Zeiss photo microscope. Parameres, osteolar peritreme and dorsal view of males were illustrated by means of line drawings using a light camera and a drawing tube of 0.1 and $0.2 \mathrm{~mm}$ of diameters.

Adults were photographed and compared to other Caribbean taxa. Right and left parameres were also photographed and compared with Dallasiellus gonostylus patterns described by Froeschner [6]. The types were placed at the Universidad Nacional Autonoma de Mexico (UNAM) and voucher material was deposited at Colecciòn Nacional de Insectos (CNIN), Mexico, D.F with collection number: 12.2010CNIM.

\section{Results and Discussion}

Dallasiellus varaderensis nov. sp. Marrero et Mayorga (Figures 2-4). Description. Male. Dark brown color. Total Body length (5.32).

\subsection{Structural Characteristics and Measurements}

Head: dorsal coloration, dark brown; antenna pale brown. Short, nearly the half of the width: length (0.67), width (1.40). A complete dorsal carine on margin is there. Tylus: convex; slightly longer than jugum and with two setigerous punctures. Jugum with eight long setigerous punctures (0.45) and six short setae (0.09). Rostrum reaching middle coxae; rostral segments: I (0.18); II (0.63); labial segments III and IV equal (0.54).

Eyes red, strongly projecting with a short transverse setae $(0.18)$ under eyes and two setigerous punctures in front of them. Small ocelli are there; interocular space (0.45), interocellar distance (0.27). Antennal segments: the first shortest I (0.26); II-III (0.27); IV (0.35); V (0.36) with a narrow ring between IV and V segments (Figure 2(a), Figure 2(b)).

Pronotum: dorsal coloration, dark brown. Pronotal length; short, nearly two times as wide as long (W/L: width (2.70)/length (1.53) (Figure 2(a), Figure 2(b)). Anterior margin moderately concave. Anterolateral borders with six long setae. 


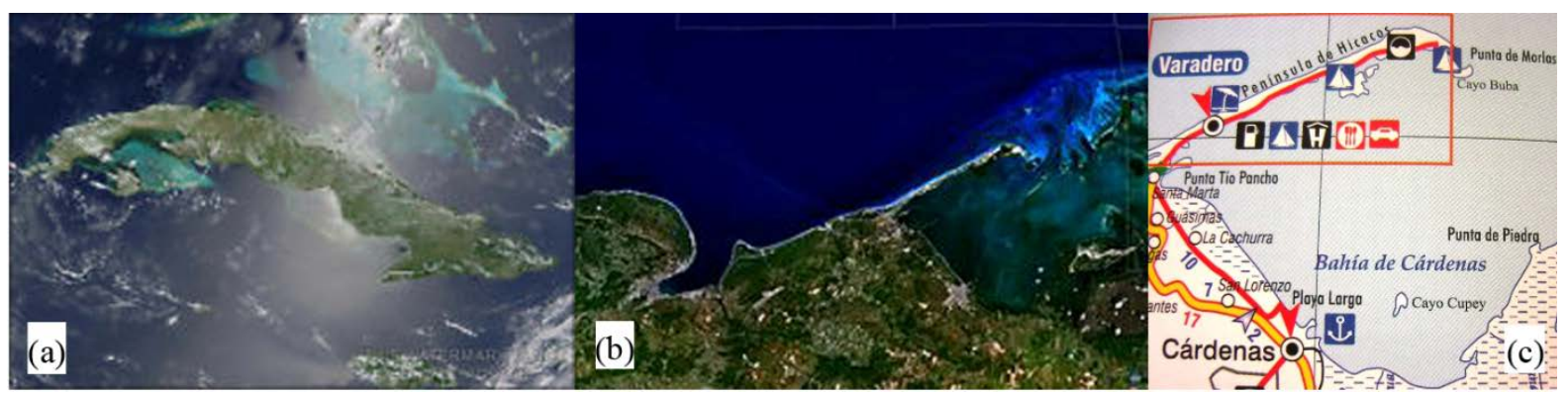

Figure 1. Study area: (a) Hicacos Peninsula; (b), (c) Aerial view of sites sampling (Varadero Golf Course: $14^{\text {th }}$ and $17^{\text {th }}$ holes).

Scutellum: dark brown color, with fine punctures and a row of setigerous punctures on lateral margins. Scutellar length (1.89); width (1.44). Sharpened apex and shinning surface (Figure 2(a)).

Legs: dark brown coloration and moderately long (Figure 2(a), Figure 2(b)). Fore legs: tibiae slightly dilated, with a row of seven black spines on outer margin. Total length: femora (0.54), tibiae (0.72), tarsi: first and third segments equal I - III (0.09), the second shortest II (0.07). Hind legs: length: femora (1.17); hind tibiae longer than protibia (1.79); not compressed and armed with double row of seven long spines on outer margin (Figure 2(b)).

Hemelytra: brown; clavus with basal area and apical portion lighter with an incomplete row of punctures. Mesocorium brown pale with two complete and an incomplete row of punctures paralleling clavocorial suture. Exocorium darker with a serie of fine punctures. Membranal suture nearly straight; membrane hyaline with some yellowish brown stains on apico-medial portion. Slightly longer than basal width and passing apex of abdomen (Figure 2(a), Figure 2(b)).

Metapleuron with evaporatorium extended through the pleurae and with setigerous punctures on the hind margin. Osteolar peritreme searching the half part of pleurae and slightly curved on middle third (Figure 3).

Abdomen: ventrally convex and covered by fine hairs; terguite VII with long setae on lateral margins; dorsal abdominal segments VI and VII dark brown.

Terminalia: genital capsule yellow brown, with apical polished punctures.

Parameres: broad of sharp apex with long setigerous punctures. Surface with dense and shorter setigerous punctures; ventrally with sinuated laminar structure in the middle part and toothed margin (Figure 4(a), Figure 4(b)).

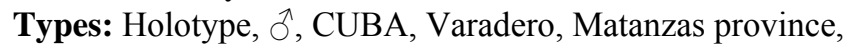

Varadero: Golf Field, 5 December/2010, L. Marrero (CNIN).

Paratype: CUBA, 1 , , same location as holotype, (CNIM).

Distribution: only known from the province of Matanzas in Cuba.

Etymology: named for its occurrence on Varadero Beach (Cuba).

\subsection{Biological Observations}

Two male of Dallasiellus varaderensis were detected during December 2010 associated to Varadero Golf turf grass. One of them was found feeding on Cynodon dactylon L. and Ficus elastica Roxb roots and other specimen was collected under the crown of Guaiacum sanctum L. feeding on seeds of the last one host.

A little biological information about Dallasiellus Berg is available and just isolated reports about their distribution and behavior in Cuba have been made [13] [14], however their occurrence feeding on fallen leaves has been previously notified [5]. Some species of Dallasiellus associated to Ficus spp. at coastal localities of the continental United States and Mexico have been found [12] [15].

In the present work $D$. varaderensis was also attracted by a light trap and it was found associated to Dallasiellus scitus (Walker.), Tominotus communis Uhler and Amnestus trimaculatus Stal. Although D. varaderensis was allied to $D$ scitus; the larger sizes of $D$. scitus (5.86 - $6.6 \mathrm{~mm}$ ); their coloration almost black; hemelytra (costa with two setigerous punctures) and the genital capsule with apical margin with a very shallow broad $\mathrm{V}$-shaped, serve to distinguish these species.

The new species described in this paper was compared with other Cuban taxa which are deposited at the Entomology Collection of Ecology and Systematic Institute (IES) and at Museum of Natural History. D. va- 

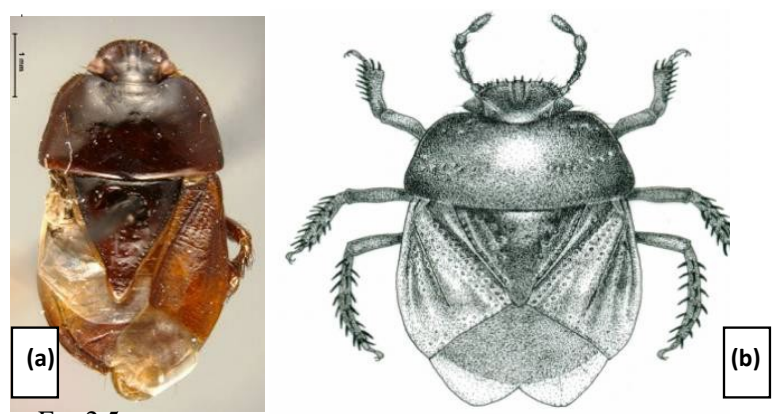

Esc 2.5

Figure 2. 40× Dorsal view of Dallasiellus varaderensis nov. sp. (a) Real insect; (b) Drawing of insect.

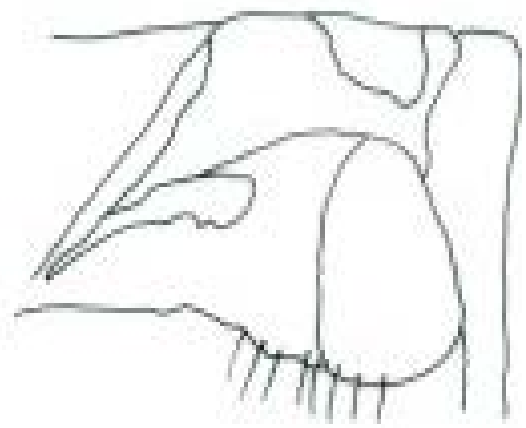

Figure 3. Ventral view of Metapleuron: evaporatorium and osteolar peritreme in Dallasiellus varaderensis nov. sp.

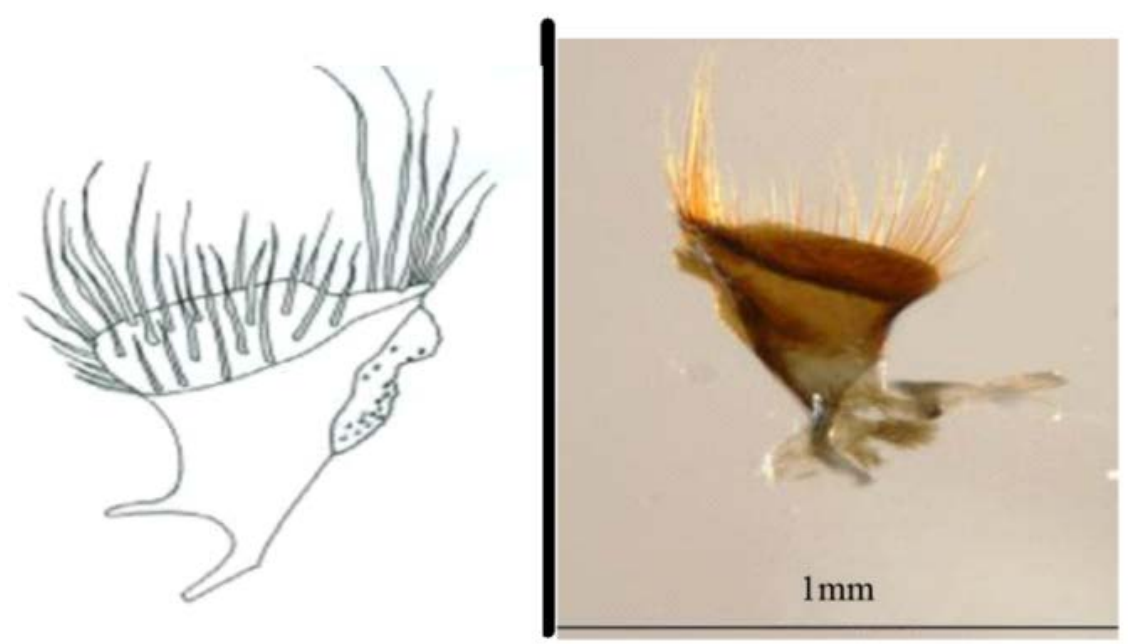

Figure 4. Lateral view of parameres in Dallasiellus varaderensis nov. sp.

raderensis showed significant differences from $D$. lugubris and $D$. scitus, the only two species of the genus described until now for the Island [5] [14].

The specimen showed marked differences from 29 species described by Froeschner [6] and deferred from Dallasiellus species listed for Mexico [12]. In addition no similar specimens were found in the National Insect Collection (CNIN) of this country. The specimen also defers from the Dallasiellus species listed for Florida [16]; Dominican Republic and Haiti [17] and from the species registered in the List of Pentatomidae in Bishop Museum Collections [18]. 
The biodiversity studies about Heteroptera on coastal localities near the Florida Strait and particularly in Varadero Golf Course are not enough yet and it is probable that more new species of Cydnidae will be found if intensive collecting is carried out. As such, it is imperative to develop future soil samplings to update the Cydnidae records from the Island.

\section{Conclusion}

An undescribed Dallasiellus species from Caribbean, Dallasiellus varaderensis nov. sp. was discovered. The taxonomic study presented here contributes for comprehensive treatment of the Cydnidae fauna of this region.

\section{Acknowledgements}

Special thanks to the authorities of Colecciòn Nacional de Insectos (CNIN) of Mexico for the assistance with specimens and to Dr. Harry Brailovsky (Instituto de Biologia, UNAM, D.F) and Dr. Luis Cervantes (Instituto de Ecología, A.C, Xalapa, Veracruz) for his comments about the manuscript. We also thank Natalie Ramirez for the outstanding illustrations. The first author wishes to thank the professor Guillermina Ortega and Javier Garcia Figueroa from UNAM, for their generous support and is grateful to Christine Zhong for their kindness. The significant comments of the anonymous reviewers served to strengthen the manuscript.

\section{References}

[1] Lis, J.A. (2006) Cydnidae Billberg, 1830-Burrowing Bugs (Burrower Bugs) In: Aukema, B. and Rieger, H., Eds., Catalogue of the Heteroptera of the Palearctic Region, Volume 5. Pentatomomorpha II, The Netherlands Entomological Society, Wageningen, 119-147.

[2] Becker, M., Schaefer, C.W. and Lis, J.A. (2000) Heteroptera of Economic Importance. CRC Press, Boca Raton, 405419. http://dx.doi.org/10.1201/9781420041859.ch12

[3] Lis, J.A., Lis, B., Kocorek, A. and Czaja, J. (2008) Cydnidae General Information: Family Cydnidae Billberg, 1820. Heteroptera Study Group, Department of Biosystematics, Opole University, Opole. http://www.cydnidae.uni.opole.pl/shownews.php?cat=1\&lang=en

[4] Mayorga, M. and Cervantes, L. (2009) Two New Species of Amnestus from Guatemala, with Next Records for Some Other Guatemalan Burrower Bugs (Hemiptera: Heteroptera: Cydnidae). Zootaxa, 2311, 19-37.

[5] Marrero, L., Mayorga, M.C., Martínez, M.A., Font, M., Duquezne, J.C., León, R. and Baños, R. (2012) Chinches subterráneas (Hemiptera: Cydnidae) asociadas a hospedantes de interés económico en la provincia de Matanzas. Protección Vegetal, 27, 194-196.

[6] Froeschner, R.C. (1960) Cydnidae of the Western Hemisphere. Proceedings of the United States National Museum, 111, 337-680. http://dx.doi.org/10.5479/si.00963801.111-3430.337

[7] Froeschner, R.C. and Capriles, J.M. (1992) A Sinopsis of Burrowing Bugs of Puerto Rico with Description of a New Species Melanaethus wolcotti. Journal of Agriculture of the University of Puerto Rico, 76, 177-185.

[8] Guerrero, K. (2005) Reporte de fauna de invertebrados en Cueva de las Maravillas, San Pedro de Macorís. República de Dominicana. http://www.habilitacionmaravillas.blogspot.com/2005/reporte\%20de\%20fauna\%20de\%20inverbretados.html

[9] Barber, H.G. and Bruner, S.C. (1932) The Cydnidae and Pentatomidae of Cuba. Journal of Department of Agriculture Puerto Rico, 16, 231-285.

[10] Alayo, P. (1967) Catálogo de la Fauna Cubana No. XXII. Los Hemípteros de Cuba VI: Familia Cydnidae. Informe de Investigación, Academia de Ciencias de Cuba, La Habana, 125-130.

[11] Zayas, F. (1988) Entomofauna cubana. Tomo VII. Editorial Científico-Técnica, La Habana, 213-217.

[12] Mayorga, M.C. and Cervantes, L. (2006) Cydnidae (Hemiptera: Heteroptera) del Centro de Investigaciones Costeras La Mancha, Actopan, Veracruz, México. Revista Mexicana de Biodiversidad, 77, 205-214.

[13] Castellòn, M.C., del Llano, J., Folgueras, M., González, J. and Fuentes, H. (1988) Estudio del agente causal de la viruela de la yuca (Manihot esculenta Crantz), en la provincia de Pinar del Rio. Ciencia y Técnica en la Agricultura: Viandas Tropicales, 11, 25-32.

[14] Grillo, H. (2012) Heteroptera of Cuba. Ph.D. Second Dissertation, Martha Abreu University, Santa Clara, 500.

[15] Henry, T.J. and Froeschner, R.C. (1988) Catalog of the Heteroptera, or True Bugs of Canada and the Continental United States. E. J. Brill, Leiden.

[16] Smith, R. and Holmes, A. (2002) Literature-Based Key to Florida “Burrowing Bugs” (Heteroptera: Cydnidae). 
Publication ENY 4161/6166. Insect Classification. University of Florida, Gainesville, 1-5.

[17] Perez, D.E. (2008) Arthropods of Hispaniola (Dominican Republic and Haiti): A Checklist and Bibliography. Zootaxa, 1831, 1-530.

[18] Rider, D. (1998) List of Pentatomidae in Bishop Museum Collections. http://www.bishopmuseum.org/research/natsci/ento/database/penta.html 